\begin{tabular}{lr}
\hline PRACE NAUKOWE UNIWERSYTETU EKONOMICZNEGO WE WROCLAWIU \\
RESEARCH PAPERS OF WROCŁAW UNIVERSITY OF ECONOMICS & nr 491 • 2017 \\
\hline Współczesna ekonomia a rozwój zrównoważony & ISSN 1899-3192 \\
& e-ISSN 2392-0041
\end{tabular}

\author{
Hanna Adamska, Stanisław Minta \\ Uniwersytet Przyrodniczy we Wrocławiu \\ e-mail: hanna.adamska@upwr.edu.pl
}

\title{
SUSTAINABLE DEVELOPMENT OF AGRICULTURE AND RURAL AREAS IN THE LIGHT OF PROGRAMS OF STRATEGIC DEVELOPMENT
}

\section{ROZWÓJ ZRÓWNOWAŻONY ROLNICTWA I OBSZARÓW WIEJSKICH W ŚWIETLE DOKUMENTÓW STRATEGICZNYCH}

DOI: $10.15611 /$ pn.2017.491.01

JEL Classification: R, O, Q

\begin{abstract}
Summary: One of the key challenges of present agriculture and rural areas is the pursuit of sustainable development. Encompassing enormous resources of a natural nature, rural areas should develop in accordance with the principles of sustainable development so that both current and future generations can benefit of them. Implementing the concept of sustainable development in rural areas is conditional on many factors and requires corrective activities, which is connected with the intervention of the state. The paper analyzes programs and instruments to support agricultural development and rural development in line with the concept of sustainable development at national and local level. Particular attention has been paid to "the Strategy of Lower Silesia Voivodship" and "Strategy for sustainable development of rural, agricultural and fisheries for 2012-2020".
\end{abstract}

Keywords: rural area, agriculture, sustainable development, development strategy.

Streszczenie: Jednym z kluczowych wyzwań współczesnego rolnictwa i obszarów wiejskich jest dążenie do rozwoju zrównoważonego. Obejmujące ogromne zasoby o charakterze przyrodniczym, obszary wiejskie powinny rozwijać się zgodnie z zasadami rozwoju zrównoważonego, aby mogły z tych zasobów korzystać tak obecne jak i przyszłe pokolenia. Realizacja koncepcji rozwoju zrównoważonego na terenach wiejskich uwarunkowana jest wieloma czynnikami i wymaga działań korygujących, co wiąże się z interwencją państwa. W artykule dokonano analizy programów i instrumentów, których zadaniem jest wspieranie działań rozwojowych rolnictwa i obszarów wiejskich zgodnie z koncepcją rozwoju zrównoważonego na szczeblu krajowym i lokalnym. Szczególną uwagę zwrócono na „Strategię województwa dolnośląskiego” oraz „Strategię zrównoważonego rozwoju wsi, rolnictwa i rybactwa na lata 2012-2020".

Słowa kluczowe: obszary wiejskie, rolnictwo, rozwój zrównoważony, strategia rozwoju. 


\section{Introduction}

Sustainable development is one of the main development concepts that has been developing since the 1980s. The Brudtland Report published in 1987, defined for the first time the meaning of sustainable development, which states that "it is such economic and social development that it will meet the needs of modern society without decreasing the ability to meet the needs of future generations" [Raport Światowej... 1991]. The report gave rise to a number of scientific and political interests in the world and in Poland. More attention has been paid to meeting the needs of society at the expense of nature, the needs of the present generation at the expense of future generations [Borys, Fiedor 2008]. Continuing its sustainability efforts were many international initiatives. Especially, the United Nations conference in Rio de Janeiro (1992) entitled "Environment and Development" should be considered the most important for promoting the idea of sustainable development. Environmental protection has become increasingly important, resulting in a series of actions. One of the first in Poland is the adoption of the National Environmental Policy which, according to Górka [2010], has become a conscious and purposeful activity with a view to rational use and protection of the natural environment in accordance with the principles of sustainable development. As a result, many political and strategic documents have emerged in Poland and in the EU, where they have been declared towards sustainable development [Kociszewski 2013].

Sustainable development means a balance between environmental, social and economic dimensions [Minta et al. 2013]. These dimensions should be interlinked and complementary without disturbing the socio-economic development of rural areas, aiming at integrated order as the primary objective of this concept. Rural areas are a specific part of the our country where are huge natural resources including nature, landscape and culture. These resources are used by the whole society as valuable public goods. Rural areas are economically, socially and environmentally diverse and require specific development measures, including those in line with the paradigm of sustainable development.

The aim of study is to analyze guidelines related to the implementation of the concept of sustainable development of agriculture and rural areas included in the Polish state and regional documents. The analysis focused primarily on "the Strategy for Sustainable Development of Rural, Agriculture and Fisheries for the years 2012-2020 " and "the Strategy of the Lower Silesian Voivodeship".

\section{Essence of sustainable development of agriculture and rural areas}

There are many changes in rural areas. However, it is difficult to imagine a village without agricultural production. Despite the declining share of agriculture in the 
income of the rural population, it will continue to be a key economic function. Ensuring sustainable development of agricultural production must take place through qualitative changes in the approach to effects of work, production of goods and public goods [Czyżewski, Kułyk 2016]. The declining share of agriculture in people's income, as reported by Kłodziński [2012], is that in $200155 \%$ of people over 15 were connected with a farm and in 2011 only $40.6 \%$. It follows that nearly $15 \%$ of this number has decreased. On the other hand, the number of people living off-farm has increased from 32.5\% in 2001 to 45\% in 2011 [Kłodziński 2012]. This phenomenon is still growing. At present, more than $60 \%$ of the rural population is unrelated to agricultural production, and rural areas are beginning to play many other functions (residential, manufacturing, service, water, recreational, construction and protection). Reducing the primary function of agriculture as a producer of food and agricultural raw materials and increasing the share of other functions in rural areas requires a special approach to development processes there. Their internal specificity must be based on development activities tailored to local differentiation. Variability of rural areas and variety of problems that are taking place here should be the basis of the differentiated actions depending on the existing possibilities [Adamska 2015]. Future image of village in Poland will be created by many processes. Very important is here environment and landscape, so as to keep the identity of the countryside for future generations [Wilkin 2011]. So the development of agriculture and rural areas should be based on the paradigm of sustainable development, covering the three spheres: economic, social and environmental.

Sustainable development of rural areas takes into account four aspects: territorial diversity, multifunctionality, democracy (participation of all actors interested in the development concept) and dynamic concept resulting from long-term changes in applied technologies, economic structures, social attitudes, standards of behavior and environmental patterns. It suggests that development of rural areas in Poland must involve many disciplines and issues with particular attention to the territorial dimension. Only this approach gives the opportunity to carry out development activities in line with the concept of sustainable development [Paszkowski 2000].

\section{Selected national documents relating to the sustainable development of agriculture and rural areas}

Implementing the principles of sustainable development requires the preparation of specific documents, which are reflected in the legislative acts, political documents or development strategies relating to the various levels: national, regional and local. As the first such document can be regarded "Ecological Policy of the State" adopted in 1991. Ecological policy has become a conscious and deliberate activity with a view to rational use and protection of the environment in accordance with the principles of sustainable development [Górka 2010]. This was the first political 
document prepared in Poland relating to sustainable development and environmental problems. It should be noted that this document was created even before the Rio de Janerio Earth Summit. Environmental policy activities were closely linked to the environment and were modified in subsequent years, adapting to the EU guidelines.

References to the concept of sustainable development can also be found in the Constitution of the Republic of Poland dated April 2, 1997 [Dz.U. 1997, no 78, pos. 483] and the Law of Environmental Protection of April 27, 2001, defining: "Sustainable development is understood as such a socio-economic development in which the process of integrating political, economic and social activities takes place with the preservation of the natural balance and the sustainability of the natural processes set to ensure that the basic needs of particular communities or citizens of both the present and future generations are met". [Dz.U. 2001, no. 62, pos. 627, art. 3, p. 50]. As Bukowski writes [2009], the issue of sustainable development contained in the Constitution of the Republic of Poland takes the form of a program's norm to setting goals in Poland's activities.

The documents that define the overall direction of development are strategies. In 2000, a long-term strategy for sustainable and balanced development was adopted. According to Kozłowski [2005], it was based on the concept of sustainable and balanced development which means that it assumes social, environmental and economic aspects. The strategy was elaborated in mid- and short-term strategies as well as sectoral plans and programs. Thus, activities related to the assumptions of sustainable development relate to the level of all fields in the form of adopted documents. The basis for rural development is a strategy that sets priorities and challenges for their development. They are based on EU Community guidelines, but Member States create their own national or regional rural development programs, adapting to the conditions and needs of the area. Development activities at local level must be based on development strategies [Wiatrak 2012].

"The Strategy for Sustainable Development of Rural, Agriculture and Fisheries" is a key document defining the direction of rural development for 2012-2020. It was adopted on 25.04.2012. The main objective of the strategy is to improve the living conditions of rural communities and to make efficient use of resources and potential in rural areas for sustainable development [Żmija 2014]. The strategy is in line with the National Development Strategy for 2007-2015, where one of the priorities is rural development. It also includes key conditions for rural development, agriculture and fisheries in the perspective of 2020, and directions for national and community public intervention. The main goal of the strategy is to "improve the quality of life in rural areas and the efficient use of their resources and potentials, including agriculture and fisheries for sustainable development." Actions that pursue the main goal of the strategy are to focus on the social, economic and environmental aspects referring to five specific objectives:

1. Increasing the quality of human capital, employment and entrepreneurship in rural areas. 
2. Improving living conditions in rural areas and mitigating their spatial isolation.

3. Food security.

4. Increasing the competitiveness of the agro-food sector.

5. Environmental protection and adaptation to climate change in rural areas [http 2].

All the objectives of the strategy are equally important, but the aspects of rural society, quality and living conditions are at the forefront. Priority in actions is to include among other things: raising skills, level of education and increasing occupational mobility of rural residents, increasing employment, developing entrepreneurship and non-agricultural employment using internal potential, preventing and reducing social exclusion. Priority in improving the living conditions of the rural population is to be understood as infrastructure development.

In order to achieve the goals of the strategy, thoughtful actions are needed. Identifying priority actions that result in certain benefits is expected to achieve the goals that should foster sustainable rural development [Roszkowska-Mądra 2009]. Activities will be diversified, resulting from the needs and development opportunities of individual territories, including rural areas.

Till 2010, regional policy was dominated by cohesion policy (linked to Community objectives). In 2008, the Ministry of Regional Development began work to organize the country's development management system. The result of this work was a document of a regional character, i.e. "the National Strategy for Regional Development 2010-2020: regions, cities, rural areas". It was adopted on July 13, 2010. The Strategy sets regional policy objectives for specific territories, including in particular rural areas, defining relations to other public policies with territorial focus [Ministerstwo Rozwoju... 2010]. Its strategic goal is to effectively use development potentials to achieve the country's development by:

- strengthening the competitiveness of regions,

- building territorial cohesion and counteracting marginalization in problem areas,

- creating the conditions for effective, effective and partnership-based implementation of territorially-oriented development measures.

It can therefore be stated that the National Strategy for Regional Development 2010-2020 is setting the direction of development based on competitiveness, consistency and effectiveness. One of the main objectives of this strategy is to counter marginal processes in problem areas. Rural areas included in this group require special actions. They will be based on the development of human capital, accessibility to goods and services, the use of endogenous factors as opportunities for their development.

Every region and municipality is doing its own development strategy on the basis of national documents. It identifies its strengths and weaknesses, and also takes into account the economic, social and environmental aspects. The effectiveness of the application of national and regional guidelines for the implementation of the concept of sustainable development depends on the state of local authorities [Kokoszka 
2012]. It is worth mentioning that in the process of implementing the strategy and its effectiveness, personnel in local offices and the level of socialization in the creation of strategic documents play an important role. If there are problems in this area, then this will be a weakness of the strategies developed [Czaja, Becla 2007]. The initiative, creativity and self-reliance of local authorities helps in meeting the assumptions, but it is often not enough to succeed, because the development strategy is the result of a number of factors (such as objectives, location and resources, local community, business entities [Blakely, Green Leigk 2009]. Frequently a problem is that while strategies define sustainable development priorities, they are often poorly utilized at the level of development management, and are only written because they help to obtain EU funding.

In the Lower Silesian Voivodeship the strategy is the most important document of the region's development based on its potential. It helps to pinpoint activities in a region that foster sustainable development. The New Development Strategy for Lower Silesian Voivodeship 2020 takes into account the specificity of each part of the region. The developmental problems of Lower Silesia are centered around diverse areas - often with a peripheral character where rural areas are also included. Here the weaknesses are: depopulation in peripheral areas, land fragmentation, high unemployment, insufficient access to services, threatening social, economic and environmental degradation. For these reasons, the New Lower Silesian Development Strategy outlines the following priorities for rural areas:

- strengthening the restructuring and multifunctional development of the countryside,

- rational organization of the agricultural production area,

- improving living conditions in rural areas,

which will be implemented through the activities of the National Rural Network, the Lower Silesia Village Renewal Program, revitalization of degraded rural areas, programming and realization of farm and equipment works, support for actions to increase food self-sufficiency of the region (food production and processing), creation of own brand of Lower Silesian products, improvement of access to markets, supporting agrienvironmental measures (especially in valuable natural and landscape areas), promotion of investments to increase productivity and energy efficiency in agribusiness (together with reduction of greenhouse gas emission), and protection of land of the highest quality class [http 1].

\section{Conclusions}

In pursuit of integrated order of the whole country there are needs to promote the sustainable development of rural areas. Because of their specific characteristics, they require a special approach due to their diversity and rich natural and cultural resources. The development of strategic documents tailored to the specificity of the countryside and the proper implementation of the concepts contained therein will 
foster the implementation of the principles of sustainable development, which should be regarded as desirable for natural, social and economic reasons.

Before the accession to the EU Poland took action to promote sustainable development primarily through relevant provisions in the Constitution of the Republic and by developing the basics of Ecological Policy of the State. However, significant progress has taken place after the accession to the EU structures. This is due to the European Union's actions, which set the direction for the development of the Member States. By adapting to these guidelines, individual countries prepare their own constitutional documents and national, regional or local strategies tailored to EU requirements.

\section{References}

Adamska H., 2015, Zrównoważony rozwój obszarów wiejskich na przykładzie Dolnego Śląska, Wyd. Uniwersytetu Przyrodniczego we Wrocławiu, Wrocław, p. 242.

Blakely E.J., Green Leigk N., 2009, Planning Local Economic Development, Wyd. Thousand Oaks: Sage. Theory and Practice, no. 4, pp. 101-113.

Borys T., Fiedor B., 2008, Operacjonalizacja i pomiar kategorii zrównoważonego rozwoju - przyczynek do dyskusji, [in:] M. Plicha (ed.), Rachunki narodowe Wybrane problemy i przyklady zastosowań, Wyd. Główny Urząd Statystyczny i Uniwersytet Łódzki, Łódź, p. 117.

Bukowski Z., 2009, Zrównoważony rozwój w systemie prawa, Wyd. Dom Organizatora, Toruń, p. 698.

Czaja S., Becla A., 2007, Wybrane problemy przygotowania i realizacji lokalnych strategii rozwoju zrównoważonego (na przykładzie gmin i społeczności lokalnych regionu watbrzyskiego), Prace Naukowe Akademii Ekonomicznej we Wrocławiu nr 1164, pp. 164-182.

Czyżewski A., Kułyk., 2016, Ksztattowanie rozwoju trwale równoważonego w ekonomii rolnej w optyce historycznej $i$ współczesnej, Prace Naukowe Uniwersytetu Ekonomicznego we Wrocławiu, nr 452, pp. 32-45.

Górka K., 2010, Wdrażanie koncepcji zrównoważonego rozwoju, [in:] Zrównoważony rozwój na poziomie lokalnym i subregionalnym, Teoria i praktyka, Wydawnictwo Uniwersytet Łódzki, Łódź, pp. 10-25.

Kłodziński M., 2012, Polityka rozwoju obszarów wiejskich, Roczniki Naukowe SERiA, tom XIV, zeszyt 3, Wyd. Wieś Jutra, Warszawa, p. 178.

Kociszewski K., 2013, Ekologizacja polskiego rolnictwa a jego zrównoważony rozwój w warunkach członkostwa w Unii Europejskiej, Monografie i Opracowania Uniwersytetu Ekonomicznego we Wrocławiu nr 227, Wrocław.

Kokoszka K., 2012, Instrumentarium zrównoważonego rozwoju-wytyczne polityki krajowej, Roczniki Naukowe SERiA, tom XIV, zeszyt 3, Wyd. Wieś Jutra, Warszawa, p. 182.

Konstytucja Rzeczypospolitej Polskiej z dnia 2 kwietnia 1997 r. Dz. U. 1997 Nr 78 poz. 483.

Kozłowski S., 2005, Przyszłość ekorozwoju, Wydawnictwo KUL, Lublin.

Ministerstwo Rozwoju Regionalnego, 2010, Krajowa Strategia Rozwoju Regionalnego 2010-2020: Regiony, Miasta, Obszary wiejskie. Dokument przyjęty przez Radę Ministrów dnia 13 lipca 2010 r. Warszawa,

Minta S., Tańska-Hus B., Nowak M., 2013, Koncepcja wdrożenia produktu regionalnego „,Wołowina Sudecka” w kontekście ochrony środowiska, Rocznik Ochrona Środowiska, Tom 15, p. 2890. 
Paszkowski S., 2000, Rozwój zrównoważony w ujęciu europejskiej konferencji na temat rozwoju wiejskiego w Cork ,, Rural Europe - Future perspectives”, Roczniki Naukowe SERiA, tom II, zeszyt 4, Wyd. Wieś Jutra, Warszawa, pp. 18-25.

Raport Światowej Komisji do Spraw Środowiska i Rozwoju, 1991, Nasza Wspólna Przyszłość, PWE, Warszawa, p. 67.

Roszkowska-Mądra B., 2009, Koncepcje rozwoju europejskiego rolnictwa i obszarów wiejskich, Gospodarka Narodowa, no. 10, pp. 83-102.

Ustawa z dnia 27 kwietnia 2001 r. Prawo ochrony środowiska. Dz. U. 2001 Nr 62 poz. 627, art. 3, p. 50.

Wiatrak A.P., 2012, Strategia gminy jako narzędzie rozwoju obszarów wiejskich. Roczniki Naukowe SERiA, tom XIV, zeszyt 3, Wyd. Wieś Jutra, Warszawa, p. 425.

Wilkin J., 2011, Jak zapewnić rozwój wsi w warunkach zmieniającej się roli rolnictwa, [in:] M. Halamska (ed.), Wieś i rolnictwo jako przedmiot badań naukowych na początku XXI wieku, Wyd. Scholar, Warszawa, p. 117.

Żmija D, 2014, Zrównoważony rozwój rolnictwa i obszarów wiejskich w Polsce, Polityka gospodarcza w okresie transformacji i kryzysu, Studia Ekonomiczne Uniwersytetu Ekonomicznego w Katowicach, nr 166, pp. 149-158.

\section{Websites}

[http1] http://www.umwd.dolnyslask.pl/fileadmin/user_upload/Rozwoj_regionalny/SRWD/SRWD_ 2020-final.pdf (access 11.06.2017).

[http2] http://www.minrol.gov.p1/Informacje-branzowe/Strategia-zrownowazonego-rozwoju-wsi-rolnictwa-i-rybactwa-na-lata-2012-2020 (access 31.08.2017). 